\title{
Relationship Between Health Practices and Education Level in the Rural Japanese Population
}

\author{
Yukiko Anzai ${ }^{1}$, Takayoshi Ohkubo ${ }^{2}$, Yoshikazu Nishino ${ }^{2}$, Ichiro Tsuji ${ }^{2}$, and Shigeru Hisamichi ${ }^{2}$
}

\begin{abstract}
Past studies in Europe and the USA have found that people with higher education levels have better health practices. The aim of this study was to examine the association between health practices and education level among people in a rural Japanese community. Data were derived from the Ohsaki National Health Insurance Cohort Study, which has been following 52,029 NHI beneficiaries, aged 40 to 79 years, in Miyagi Prefecture, Japan. The relationship between education level and seven health indices (smoking, drinking, body mass index, sleeping, exercise, breakfast, and snacks) was analyzed. Higher education was associated with shorter sleeping hours for both men and women, and lower BMI for women. In age groups younger than 70 years, people with higher education tended to exercise more. Smoking for women, alcohol consumption, and a Health Practices Index were not related to education levels. These results are different from those from Europe and the USA. This study suggest that the relationship between health practices and education level is weaker in Japan than in Europe and the USA.

J Epidemiol, $2000 ; 10: 149-156$
\end{abstract}

education level, health practice, smoking, alcohol, body mass index, Japanese

Socioeconomic status (SES) is a major determinant of health status and subsequent mortality ${ }^{1-5}$. In addition to different levels of access to health care by SES, one explanation for this association is that people's health-related lifestyles are dictated by SES. Studies in Europe and the USA have found that people with a higher education level, a typical proxy variable for SES, have lower rates of smoking, excessive alcohol consumption, obesity and moderate physical activity ${ }^{6-14}$.

However, no study has yet examined the relationship between health-related lifestyle and education level in the Japanese population. The basic education level in Japan is higher than in Europe and the USA, but income is less strongly associated with education level ${ }^{15-17}$. It is not clear whether the relationship between health practices and education level identified in Europe and the USA exists in Japan. Knowledge of the relationship would lead to better health education and services for the community.

The purpose of this study was to examine the relationship between health practices and education level among the people living in a rural Japanese community.

\section{MATERIALS AND METHODS}

\section{Study design and subjects}

Data were derived from a baseline survey from the Ohsaki National Health Insurance (NHI) Cohort Study, which has been following $52,029 \mathrm{NHI}$ beneficiaries aged 40 to 79 years in 14 municipalities in Miyagi Prefecture, Japan, since 1994. The study design and baseline characteristics of the subjects have been described in detail ${ }^{18,19)}$. The study used a questionnaire consisting of 93 items such as: smoking history, alcohol history, alcohol volume, weight, height, sleeping hours, physical exercise, eating breakfast, eating snacks, and education.

The baseline survey was conducted from September to December 1994. Public health officials in each municipality visited each study subject at home with a questionnaire. The

Received May 31, 1999 ; accepted October 6, 1999.

'Research Unit for Public Health Nursing, Miyagi University School of Nursing, 1 Gakuen, Taiwa-cho, Miyagi-ken $981-3298$ Japan. ¿Department of Public Health, Tohoku University School of Medicine, Sendai Japan. Address for correspondence: Yukiko Anzai, Miyagi University School of Nursing, 1 Gakuen, Taiwa-cho, Miyagi-ken $981-3298$
Japan. 
subjects were informed of the study objectives and their right to decline. If they consented, they were asked to complete the questionnaire by themselves. The same public health officials visited them again about a week later to collect the questionnaire. The response rate was $94.6 \%(52,029 / 54,996)$.

\section{Study variables}

We examined the relationship between education level and seven health practices defined by Belloc and Breslow ${ }^{20)}$ smoking history, alcohol consumption, body mass index (BMI, $\mathrm{kg} / \mathrm{m}^{2}$ ), sleeping, exercise, breakfast, and snacks.

Smoking history was recorded as non-smoker, ex-smoker, or current smoker. Drinking history was recorded as non-drinker, ex-drinker, or current drinker. Current drinkers were asked about the name of alcohol beverages and its quantity consumed at one time; this was recorded as " 4 go or less at one time" or "5 go or more at one time" (a go is a traditional unit in Japan, approximately $180 \mathrm{ml}$ of sake, containing $30 \mathrm{~g}$ of ethanol). BMI was calculated from self-reported weight and height. It was recorded as underweight (< 19.8), normal (19.8-24.2), or overweight ( $>24.2$ ), based on the criteria of the Japan Obesity Society ${ }^{21)}$. Of 52,029 subjects, 16,346 men or women participated in health examination in 1995 and had their weight and height measured. These values were strongly correlated with self-reported weight and height of baseline survey (weight ; $r=0.933$, height $; r=0.929$ ). Sleeping hours in an ordinary day were recorded as $<7$ hours per night, 7-8 hours per night, or $>$ 8 hours per night. The total number of hours the subjects spent on physical exercise per week was recorded as $\geqq 3$ hours or $<$ 3 hours. Breakfast was recorded as "eating almost every day," or "not eating almost every day." The number of snacks per week was recorded as 0-2 times per week or $\geqq 3$ times per week.

Using Belloc and Breslow's scoring system ${ }^{20)}$, a Health Practices Index (HPI) was calculated (Table 1). The HPI ranges from 0 to 7 , where 7 indicates best health practice.

For education level, we asked the subjects to report their highest academic degree attained. We categorized them as junior high school (9-year education); high school (12-year education); or junior college, college, and beyond (14-year education or more).

Statistical analysis

The relationship between each health practice and education level was analyzed by using the $\chi^{2}$-test and ANOVA in SAS ${ }^{22)}$. We considered $p<0.05$ to be statistically significant. We examined each of four age groups (40-49, 50-59, 6069 , and $70-79$ at baseline) separately. This allowed us to exclude the effect of association between age and education level that exists in Japan. The proportion of people who entered high school increased from 58\% in 1960 to $>90 \%$ in 1980. The proportion of those who then entered college increased from $10 \%$ in 1960 to $>30 \%$ in $1980^{23}$.

\section{RESULTS}

Of 52,029 subjects, 34,475 (18,568 men and 15,907 women) responded to all ten questions (Table 2). Those who responded to all questions had a higher education level $(p<0.001)$ and were younger $(p<0.001)$ than those who missed one or more questions (6326 men and 11,228 women). The following findings are derived from those who responded to all questions.

\section{Smoking (Table 3)}

There tended to be fewer current smokers and more exsmokers among men with a higher education than among men with a lower education. Significant differences were found in the 40-49 age group $(p<0.01)$ and the $60-69$ age group $(p<$ 0.0001 ).

More women who had completed only junior high school (except those in the 50-59 age group) were current smokers than women in the other education groups, although current smokers were only $5 \%-20 \%$ of the subjects. A significant difference between education level of current smokers was found in the 40-49 age group ( $p<0.0001)$ : there were fewer current smokers among women with a higher education. However, in the 50-59 age group, more college graduates were current smokers than in the other education groups $(p<0.05)$. In the 60-69 age group, more college graduates were current smokers than high school graduates. Thus, a consistent relationship was not found between education level and smoking.

Table 1. Health Practice Index.

\begin{tabular}{llll}
\hline \multicolumn{1}{c}{ Variables } & \multicolumn{3}{c}{ Categories (score) } \\
\hline Smoking & Non-smoker (1) & Ex-smoker (0) & Current smoker (0) \\
Alcohol consumption & Non-drinker (1) & Ex-drinker (1) & \\
& Current drinker : $1-4$ go*/time (1) & $\geqq 5$ go/time (0) \\
Body Mass Index & $<19.8 \mathrm{~kg} / \mathrm{m}^{2}(0)$ & $19.8-24.2 \mathrm{~kg} / \mathrm{m}^{2}(1)$ & $>24.2 \mathrm{~kg} / \mathrm{m}^{2}(0)$ \\
Sleeping hours & $<7 \mathrm{hr} / \mathrm{day}(0)$ & $7-8 \mathrm{hr} / \mathrm{day}(1)$ & $>8 \mathrm{hr} / \mathrm{day}(0)$ \\
Physical exercise & $\geqq 3 \mathrm{hr} /$ week (1) & $<3 \mathrm{hr} /$ week $(0)$ & \\
Eating breakfast & Almost everyday (1) & Not eating almost everyday (0) \\
Eating snacks & $0-2$ time/week (1) & $\geqq 3$ time/week $(0)$ \\
\hline * A go is a traditional unit in Japan, approximately $180 \mathrm{ml}$ of sake, containing 30 g of ethanol.
\end{tabular}


Table 2. Number of study subjects by education, age, sex.

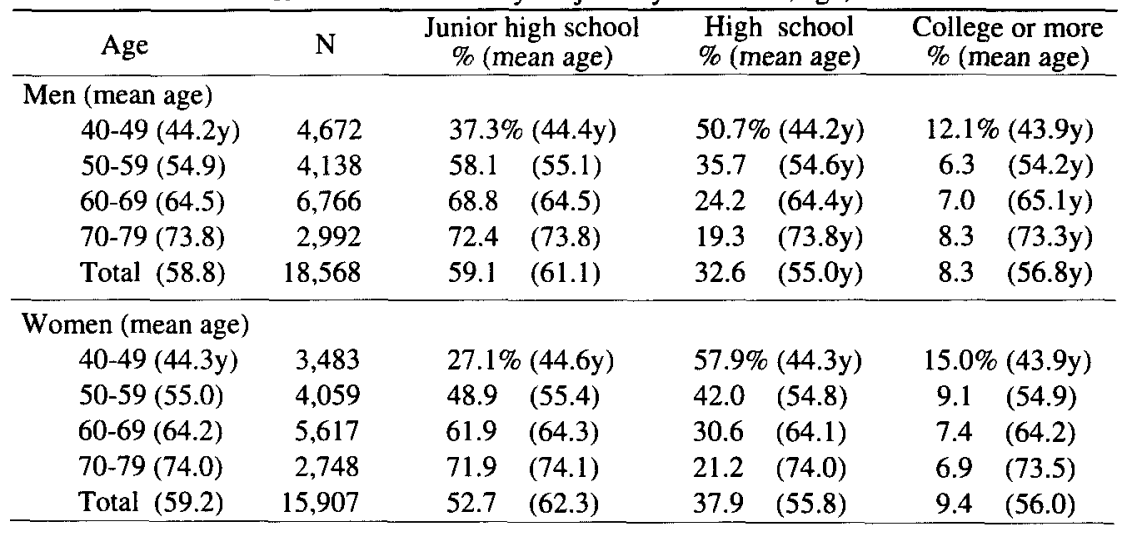

\section{Alcohol consumption (Table 3)}

Fewer men who completed only junior high school were current drinkers and more men who completed high school were current drinkers. Significant differences were found in the $40-49$ age group $(p<0.05)$, the 50-59 age group $(p<0.01)$, and the 70-79 age group $(\mathrm{p}<0.05)$.

More women who completed college (except those in the 70-79 age group) were current drinkers than in the other education groups (Table 3 ). Significant differences were found in the $40-49$ age group $(\mathrm{p}<0.0001)$ and the $50-59$ age group $(\mathrm{p}<$ $0.05)$.

\section{BMI (Table 4)}

Men in the higher education groups had a higher BMI. Except those in the 40-49 age group, fewer men in the higher education groups had a normal BMI, and more men who completed only junior high school had a normal BMI than in the other education groups.

More women in the higher education groups had a normal BMI and fewer had a high BMI; that is, fewer women were overweight. This difference was significant in all age groups ( $\mathrm{p}$ $<0.0001$ ).

\section{Sleeping hours (Table 4)}

For men, sleeping hours were significantly associated with education level $(p<0.0001)$. The higher education groups had fewer people who slept more than 8 hours and more people who slept less than 7 hours. The same association was also observed for women ( $p<0.0001)$, except those in the $40-49$ age group.

\section{Physical exercise (Table 5)}

In the 40-49 and 50-59 age groups, significantly more men with a higher education exercised three hours or more per week $(p<0.0001)$. The same association was also observed for women. In the 60-69 age group, more men who completed high school and fewer who completed only junior high school exercised three hours or more $(\mathrm{p}<0.0001)$.

\section{Eating breakfast and snacks (Table 5)}

Significantly more men (except those in the 40-49 age group) with a lower education ate breakfast every day, especially in the 50-59 age group ( $<<0.05$ ). More women in the 40-49 and the 60-69 age groups with a higher education ate breakfast every day, especially in the 40-49 age group ( $p<$ 0.0001 ). In contrast, in the 50-59 age group, those who completed high school ate breakfast every day most frequently and college graduates ate breakfast every day least frequently $(\mathrm{p}<$ 0.05 ).

There was no relationship with education level of men for snack consumption. In the 40-49 and 50-59 age groups, women who completed high school snacked the least, and women who completed only junior high school snacked the most ( $p<0.0001$ ). In the 60-69 age group, women who completed high school snacked less, and college graduates snacked the most $(p<0.05)$. In the 70-79 age group, women in the higher education groups had the fewest snacks $(p<0.05)$.

\section{Health Practices Index (Table 6)}

Among men (except those aged 70-79), there was no significant relationship between HPI and education level. Among women in the 40-49 and 60-69 age groups, the higher education groups had a significantly higher HPI ( $p<0.0001$ ). Although statistically significant, the difference between the highest and lowest HPIs was not so large (4.3 vs. 4.5 in $40-49$ age group; 4.5 vs. 4.7 in $60-69$ age group). The other age groups had no relationship between HPI and education level.

\section{DISCUSSION}

We examined the relationship between health practices and education level in adult subjects older than 40 years who live in an agricultural district in Japan. The frequencies of health 
Table 3. Percentage, $p$-value ( $\chi^{2}$-test) of smoking and alcohol consumption by education, age, sex

\begin{tabular}{|c|c|c|c|c|c|c|}
\hline Variables & Age & Categories & $\begin{array}{c}\text { Junior high } \\
\text { school }\end{array}$ & $\begin{array}{c}\text { High } \\
\text { school }\end{array}$ & $\begin{array}{c}\text { College or } \\
\text { more }\end{array}$ & p-value \\
\hline \multicolumn{7}{|l|}{ Men } \\
\hline \multirow[t]{12}{*}{ Smoking } & \multirow[t]{3}{*}{$40-49$} & Non-smoker & 16.8 & 15.5 & 16.8 & \multirow{3}{*}{0.003} \\
\hline & & Ex-smoker & 13.6 & 15.7 & 20.2 & \\
\hline & & Current smoker & 79.6 & 68.8 & 62.9 & \\
\hline & \multirow[t]{3}{*}{$50-59$} & Non-smoker & 23.3 & 23.2 & 21.2 & \multirow{3}{*}{0.360} \\
\hline & & Ex-smoker & 18.5 & 20.1 & 23.2 & \\
\hline & & Current smoker & 58.2 & 56.6 & 55.6 & \\
\hline & \multirow[t]{3}{*}{$60-69$} & Non-smoker & 18.6 & 16.5 & 15.5 & \multirow{3}{*}{$<0.001$} \\
\hline & & Ex-smoker & 28.8 & 34.0 & 46.0 & \\
\hline & & Current smoker & 52.6 & 49.5 & 38.6 & \\
\hline & \multirow[t]{3}{*}{70} & Non-smoker & 17.0 & 20.3 & 14.1 & \multirow{3}{*}{0.090} \\
\hline & & Ex-smoker & 43.3 & 43.0 & 49.6 & \\
\hline & & Current smoker & 39.7 & 36.7 & 36.3 & \\
\hline Alcohol & $40-49$ & Non-drinking & 15.5 & 12.4 & 12.9 & \multirow{3}{*}{0.032} \\
\hline \multirow[t]{11}{*}{ Consumption } & & Ex-drinking & 5.3 & 4.6 & 5.7 & \\
\hline & & Current drinking & 79.2 & 83.0 & 81.4 & \\
\hline & \multirow[t]{3}{*}{$50-59$} & Non-drinking & 14.9 & 13.9 & 18.5 & \multirow{3}{*}{0.009} \\
\hline & & Ex-drinking & 8.4 & 6.1 & 5.0 & \\
\hline & & Current drinking & 76.7 & 80.0 & 76.5 & \\
\hline & \multirow[t]{3}{*}{$60-69$} & Non-drinking & 17.1 & 16.1 & 16.9 & \multirow{3}{*}{0.872} \\
\hline & & Ex-drinking & 12.6 & 12.3 & 11.9 & \\
\hline & & Current drinking & 70.3 & 71.5 & 71.2 & \\
\hline & \multirow[t]{3}{*}{$70-$} & Non-drinking & 22.5 & 16.6 & 20.6 & \multirow{3}{*}{0.046} \\
\hline & & Ex-drinking & 22.0 & 22.5 & 22.2 & \\
\hline & & Current drinking & 55.6 & 60.8 & 57.3 & \\
\hline \multicolumn{7}{|l|}{ Women } \\
\hline \multirow[t]{12}{*}{ Smoking } & $40-49$ & Non-smoker & 76.7 & 85.2 & 84.6 & \\
\hline & & Ex-smoker & 3.1 & 2.4 & 3.4 & $<0.001$ \\
\hline & & Current smoker & 20.6 & 12.4 & 12.0 & \\
\hline & $50-59$ & Non-smoker & 88.4 & 90.9 & 86.8 & \\
\hline & & Ex-smoker & 1.8 & 1.7 & 3.2 & 0.019 \\
\hline & & Current smoker & 9.8 & 7.4 & 10.0 & \\
\hline & $60-69$ & Non-smoker & 92.2 & 94.0 & 92.6 & \\
\hline & & Ex-smoker & 2.2 & 2.0 & 2.9 & 0.101 \\
\hline & & Current smoker & 5.6 & 4.0 & 4.6 & \\
\hline & 70 & Non-smoker & 89.1 & 91.1 & 93.2 & \\
\hline & & Ex-smoker & 4.1 & 3.3 & 3.7 & 0.243 \\
\hline & & Current smoker & 6.8 & 5.7 & 3.2 & \\
\hline Alcohol & $40-49$ & Non-drinking & 56.3 & 60.6 & 53.8 & \\
\hline Consumption & & Ex-drinking & 7.2 & 4.0 & 4.8 & $<0.001$ \\
\hline & & Current drinking & 36.5 & 35.4 & 41.4 & \\
\hline & $50-59$ & Non-drinking & 70.3 & 70.1 & 63.2 & \\
\hline & & Ex-drinking & 4.7 & 3.8 & 5.1 & 0.036 \\
\hline & & Current drinking & 24.9 & 26.1 & 31.6 & \\
\hline & $60-69$ & Non-drinking & 79.2 & 79.5 & 78.7 & \\
\hline & & Ex-drinking & 4.3 & 3.5 & 2.4 & 0.226 \\
\hline & & Current drinking & 16.5 & 17.0 & 18.9 & \\
\hline & $70-$ & Non-drinking & 83.0 & 83.7 & 85.8 & \\
\hline & & Ex-drinking & 5.5 & 3.6 & 3.7 & 0.291 \\
\hline & & Current drinking & 11.5 & 12.7 & 10.5 & \\
\hline
\end{tabular}


Table 4. Percentage, p-value ( $\chi^{2}$-test) of Body Mass Index and Sleeping hours by education, age, sex

\begin{tabular}{|c|c|c|c|c|c|c|}
\hline Variables & Age & Categories & $\begin{array}{c}\text { Junior high } \\
\text { school }\end{array}$ & $\begin{array}{l}\text { High } \\
\text { school }\end{array}$ & $\begin{array}{c}\text { College or } \\
\text { more }\end{array}$ & p-value \\
\hline \multicolumn{7}{|l|}{ Men } \\
\hline \multirow[t]{12}{*}{ BMI } & \multirow[t]{3}{*}{$40-49$} & $<19.8$ & 8.9 & 7.0 & 6.7 & \multirow{3}{*}{0.053} \\
\hline & & $19.8-24.2$ & 51.1 & 52.0 & 50.7 & \\
\hline & & $>24.2$ & 40.0 & 40.9 & 43.6 & \\
\hline & \multirow[t]{3}{*}{$50-59$} & $<19.8$ & 6.4 & 6.1 & 5.0 & \multirow{3}{*}{0.117} \\
\hline & & $19.8-24.2$ & 53.8 & 52.2 & 46.7 & \\
\hline & & $>24.2$ & 39.8 & 41.7 & 48.3 & \\
\hline & \multirow[t]{3}{*}{$60-69$} & $<19.8$ & 10.3 & 10.6 & 11.0 & \multirow{3}{*}{0.640} \\
\hline & & $19.8-24.2$ & 56.1 & 54.7 & 52.8 & \\
\hline & & $>24.2$ & 33.6 & 34.7 & 36.2 & \\
\hline & \multirow[t]{3}{*}{$70-$} & $<19.8$ & 16.1 & 18.5 & 16.9 & \multirow{3}{*}{0.202} \\
\hline & & $19.8-24.2$ & 59.0 & 56.7 & 52.8 & \\
\hline & & $>24.2$ & 24.9 & 24.8 & 30.2 & \\
\hline Sleeping hours & $40-49$ & $<7$ & 13.9 & 16.0 & 18.6 & \multirow{3}{*}{$<0.001$} \\
\hline \multirow{11}{*}{ (hr/day) } & & $7-8$ & 76.2 & 77.8 & 76.6 & \\
\hline & \multirow{4}{*}{$50-59$} & $>8$ & 9.9 & 6.2 & 4.8 & \\
\hline & & $<7$ & 11.1 & 15.2 & 18.5 & \multirow{3}{*}{$<0.001$} \\
\hline & & $7-8$ & 72.6 & 72.6 & 74.5 & \\
\hline & & $>8$ & 16.3 & 12.2 & 7.0 & \\
\hline & \multirow[t]{3}{*}{$60-69$} & $<7$ & 9.0 & 13.7 & 16.5 & \multirow{3}{*}{$<0.001$} \\
\hline & & $7-8$ & 64.8 & 67.8 & 72.7 & \\
\hline & & $>8$ & 26.2 & 18.5 & 10.8 & \\
\hline & \multirow[t]{3}{*}{$70-$} & $<7$ & 10.7 & 12.1 & 15.7 & \multirow{3}{*}{$<0.001$} \\
\hline & & $7-8$ & 52.9 & 65.5 & 69.0 & \\
\hline & & $>8$ & 36.4 & 22.4 & 15.3 & \\
\hline \multicolumn{7}{|l|}{ Women } \\
\hline \multirow[t]{12}{*}{ BMI } & $40-49$ & $<19.8$ & 8.6 & 8.8 & 12.6 & \\
\hline & & $19.8-24.2$ & 50.4 & 57.0 & 61.6 & $<0.001$ \\
\hline & & $>24.2$ & 41.0 & 34.2 & 25.8 & \\
\hline & $50-59$ & $<19.8$ & 6.4 & 8.5 & 7.6 & \\
\hline & & $19.8-24.2$ & 46.1 & 51.5 & 55.4 & $<0.001$ \\
\hline & & $>24.2$ & 47.5 & 40.0 & 37.0 & \\
\hline & $60-69$ & $<19.8$ & 9.1 & 9.7 & 9.3 & \\
\hline & & $19.8-24.2$ & 44.3 & 49.9 & 51.6 & 0.001 \\
\hline & & $>24.2$ & 46.6 & 40.4 & 39.1 & \\
\hline & $70-$ & $<19.8$ & 15.8 & 19.4 & 19.5 & \\
\hline & & $19.8-24.2$ & 43.8 & 49.3 & 47.9 & 0.001 \\
\hline & & $>24.2$ & 40.4 & 31.3 & 32.6 & \\
\hline Sleeping hours & $40-49$ & $<7$ & 27.4 & 27.0 & 30.7 & \\
\hline (hr/day) & & $7-8$ & 66.4 & 70.5 & 65.8 & $<0.001$ \\
\hline & & $>8$ & 6.2 & 2.5 & 3.4 & \\
\hline & $50-59$ & $<7$ & 18.8 & 22.1 & 31.6 & \\
\hline & & $7-8$ & 71.2 & 71.1 & 61.6 & $<0.001$ \\
\hline & & $>8$ & 10.0 & 6.9 & 6.8 & \\
\hline & $60-69$ & $<7$ & 16.1 & 21.4 & 23.0 & \\
\hline & & $7-8$ & 67.4 & 68.6 & 70.3 & $<0.001$ \\
\hline & & $>8$ & 16.4 & 9.9 & 6.7 & \\
\hline & 70 & $<7$ & 13.5 & 18.4 & 21.6 & \\
\hline & & $7-8$ & 53.0 & 60.5 & 62.1 & $<0.001$ \\
\hline & & $>8$ & 33.5 & 21.1 & 16.3 & \\
\hline
\end{tabular}


Table 5. Percentage, p-value ( $\chi^{2}$-test) of physical exercise, eating breakfast and snaking by education, age, sex.

\begin{tabular}{|c|c|c|c|c|c|}
\hline Variables & Age & $\begin{array}{c}\text { Junior high } \\
\text { school }\end{array}$ & $\begin{array}{c}\text { High } \\
\text { school }\end{array}$ & $\begin{array}{c}\text { College or } \\
\text { more }\end{array}$ & $\mathrm{p}$-value \\
\hline \multicolumn{6}{|l|}{ Men } \\
\hline \multirow{4}{*}{$\begin{array}{l}\text { Physical exercise } \\
\text { ( } \geqq 3 \mathrm{hr} / \text { week) }\end{array}$} & $40-49$ & 5.9 & 7.9 & 11.3 & $<0.001$ \\
\hline & $50-59$ & 7.3 & 8.1 & 18.1 & $<0.001$ \\
\hline & $60-69$ & 17.3 & 22.4 & 22.2 & $<0.001$ \\
\hline & $70-$ & 30.8 & 28.6 & 26.6 & 0.283 \\
\hline \multirow{4}{*}{$\begin{array}{l}\text { Eating breakfast } \\
\text { (Almost every day) }\end{array}$} & $40-49$ & 86.3 & 86.8 & 85.1 & 0.554 \\
\hline & $50-59$ & 95.0 & 93.8 & 91.5 & 0.029 \\
\hline & $60-69$ & 98.0 & 97.5 & 97.7 & 0.455 \\
\hline & 70 & 99.0 & 98.4 & 98.0 & 0.267 \\
\hline \multirow{4}{*}{$\begin{array}{l}\text { Eating snacks } \\
(0-2 / \text { week })\end{array}$} & $40-49$ & 68.8 & 68.4 & 71.8 & 0.277 \\
\hline & $50-59$ & 68.4 & 66.3 & 66.8 & 0.404 \\
\hline & $60-69$ & 64.3 & 63.2 & 60.4 & 0.212 \\
\hline & $70-$ & 56.6 & 58.8 & 51.6 & 0.165 \\
\hline \multicolumn{6}{|l|}{ Women } \\
\hline \multirow{4}{*}{$\begin{array}{l}\text { Physical exercise } \\
\text { ( } \geqq 3 \mathrm{hr} / \text { week) }\end{array}$} & $40-49$ & 3.8 & 4.4 & 7.4 & 0.004 \\
\hline & $50-59$ & 6.4 & 9.5 & 10.3 & 0.001 \\
\hline & $60-69$ & 14.6 & 14.6 & 17.6 & 0.191 \\
\hline & $70-$ & 14.4 & 12.9 & 13.2 & 0.605 \\
\hline \multirow{4}{*}{$\begin{array}{l}\text { Eating breakfast } \\
\text { (Almost every day) }\end{array}$} & $40-49$ & 85.2 & 90.0 & 90.8 & $<0.001$ \\
\hline & $50-59$ & 94.2 & 94.7 & 91.1 & 0.030 \\
\hline & $60-69$ & 97.6 & 97.8 & 98.3 & 0.640 \\
\hline & $70-$ & 98.3 & 98.1 & 96.8 & 0.373 \\
\hline \multirow{4}{*}{$\begin{array}{l}\text { Eating snacks } \\
(0-2 / \text { week })\end{array}$} & $40-49$ & 45.1 & 36.0 & 38.9 & $<0.001$ \\
\hline & $50-59$ & 38.3 & 31.8 & 33.2 & $<0.001$ \\
\hline & $60-69$ & 37.4 & 35.4 & 42.0 & 0.041 \\
\hline & $70-$ & 39.2 & 35.6 & 31.1 & 0.039 \\
\hline
\end{tabular}

Table 6. Health Practice Index.

\begin{tabular}{lcccc}
\hline Age & $\begin{array}{c}\text { Junior high } \\
\text { school }\end{array}$ & $\begin{array}{c}\text { High } \\
\text { school }\end{array}$ & $\begin{array}{c}\text { College or } \\
\text { more }\end{array}$ & p-value* \\
\hline Men & & & & \\
$40-49$ & $4.0 \pm 1.03$ & $4.1 \pm 1.02$ & $4.1 \pm 1.05$ & 0.105 \\
$50-59$ & $4.2 \pm 1.00$ & $4.1 \pm 1.01$ & $4.2 \pm 0.98$ & 0.279 \\
$60-69$ & $4.2 \pm 1.01$ & $4.2 \pm 1.04$ & $4.2 \pm 1.07$ & 0.585 \\
$70-$ & $4.2 \pm 1.10$ & $4.3 \pm 1.08$ & $4.1 \pm 1.07$ & 0.030 \\
\hline Women & & & & \\
$40-49$ & $4.3 \pm 1.10$ & $4.4 \pm 1.00$ & $4.5 \pm 1.03$ & $<0.001$ \\
$50-59$ & $4.4 \pm 0.95$ & $4.5 \pm 0.99$ & $4.4 \pm 1.01$ & 0.073 \\
$60-69$ & $4.5 \pm 0.97$ & $4.6 \pm 0.97$ & $4.7 \pm 1.03$ & $<0.001$ \\
$70-$ & $4.4 \pm 0.99$ & $4.5 \pm 0.98$ & $4.4 \pm 0.95$ & 0.098 \\
\hline * Tested with ANOVA & & \multicolumn{3}{c}{}
\end{tabular}

practices by age group were consistent with the results of other large-scale, population-based cohort studies in Japan ${ }^{24,25)}$.

The results indicate that higher education is significantly associated with shorter sleeping hours for both men and women. In the age groups younger than 70 years, significantly more people with a higher education tended to exercise three hours or more per week. Alcohol consumption and HPI were not associated with education level. Smoking for men and BMI for women were associated with education level but smoking for women and BMI for men were not associated. These results are remarkably different from those from Europe and the USA ${ }^{26,2 n}$

A significant relationship between smoking and education level was found only among men in their forties and sixties and women in their forties. Among women in their fifties, most smokers were college graduates. Studies in the West indicate that people with higher education are significantly less likely to be smokers men and women ${ }^{6-8)}$. Thus the relationship between smoking and education level is weaker in Japan than in Western countries. 
Men who completed only junior high school were less likely to be drinkers. Women with a higher education were more likely to be drinkers, except those in their seventies. However, Western studies have found a negative correlation between alcohol consumption and years of education. Especially, heavy drinking had the association a lower education level ${ }^{9,10)}$.

There was no relationship between HPI and education level of men, except for men in their seventies. Among women in their forties and sixties, those with a higher education had a significantly higher HPI. Although statistically significant, the difference in HPI was only marginal (Table 6).

In summary, the relationship between health practices and education level is weaker in Japan than in Europe and the USA. There is no clear explanation for this. However, our results could have some implications. First, our findings could be interpreted to mean that formal education in Japan fails to provide effective physical education. We need to reinforce physical education to prevent students from adopting poor health habits such as smoking. Second, our results suggest us that education level is not an appropriate proxy for SES in Japan. This notion is supported by the fact that income difference by education level is small in Japan ${ }^{15-17}$. Many epidemiological studies include education level in multivariate models to control for the effect of SES on health-related outcomes. Our results suggest that, in the Japanese population, adding education level to statistical analyses would bring only a small gain.

This study deals with people in a rural area in the northern part of Japan where the education level is lower than the national average. The subjects are mainly farmers or the selfemployed. Therefore, our findings may not apply to residents in an urban area of Japan. Another limitation in this study is that only 34,475 out 52,029 original subjects responded to all questions and were analyzed. Thus, the selection bias due to omitting no complete responders should be taken into account. It is necessary to investigate other populations to test the generalizability of our findings. It is also important to identify the factors responsible for the difference between Japan and the West in the relationship between health practices and education level.

\section{ACKNOWLEDGEMENTS}

This study was supported by a Health Sciences Research Grant from the Ministry of Health and Welfare, Japan (Research on Health Services: H10-025) and a Research Grant for JSPS Research Fellow (T.O.) from the Ministry of Education, Science and Culture of Japan.

\section{REFERENCES}

1. Kallan J. Effects of sociodemographic variables on adult mortality in the United States comparisons by sex, age, and cause of death. Soc Biol 1997; 44:136-47.

2. Lantz PM, House JS, Lepkowski JM, Williams DR, Mero RP, Chen J. Socioeconomic factors, health behaviors, and mortality: results from a nationally representative prospective study of US adults. JAMA 1998; 279: 1745-6.

3. Mackenbach JP, Kunst AE, Cavelaars AE, Groenhof F, Geurts JJ. Socioeconomic inequalities in mortality in western Europe. The EU Working Group on Socioeconomic Inequalities in Health. Lancet 1997; 349: 1655-9.

4. Marang-van de Mheen PJ, Davev Smith G, Hart CL, Gunning-Schepers LJ. Socioeconomic differentials in mortality among men within Great Britain: time trends and contributory causes. J Epidemiol Community Health 1998; 52: 214-8.

5. Sundquist J, Johansson SE. Indicators of socio-economic positon and their relation to mortality in Sweden. Soc Sci \& Med 1997; 45: 1757-66.

6. Zhu BP, Giovino GA, Mowery PD, Eriksen MP. The relationship between cigarette smoking and education revisited: implications for categorizing persons' education al status. Am J Public Health 1996; 86: 1582-9.

7. Whitlook G, MacMahon S, Vender Hoom S, Davis $P$ Jackson R, Norton R. Sosioeconomic distribution of smoking in a population of 10,529 New Zealanders. $N Z$ Med J 1997; 110: 327-30.

8. Siegel D, Faigeles B. Smoking and socioeconomic status in a population-based inner city sample of AfricanAmericans, Lations and whites. J Cardiovasc Risk 1996; 3: 295-300.

9. Fillmore KM, Golding JM, Graves KL, et al. Alcohol consumption and mortality. I. Characteristics of drinking groups. Addiction 1998; 93: 183-203.

10. Ruchlin HS. Prevalence and correlates of alcohol use among older adults. Prev Med 1997; 26: 651-7.

11. Sundquist J, Johansson SE. The influence of socioeconomic status, ethnicity and lifestyle on body mass index in a longitudinal study. Int J Epidemiol 1998; 27: 57-63.

12. Winkleby MA, Gardner CD, Taylor $C B$. The influence of gender and socioeconomic factors on Hispanic/white differences in body mass index. Prev Med 1996; 25: 20311.

13. Cauley JA, Donfield SM, Laporte RE, Warhaftig NE. Physical activity by socioeconomic status in two population based cohorts. Med Sci Sports Exerc 1991; 23: 34351.

14. Ford ES, Merritt RK, Heath GW, et al. Physical activity behaviors in lower and higher socioeconomic status populations. Am J Epidemiol 1991; 133: 1246-56.

15. Amagi I. (ed.). Sougoni mita nitibei kyouiku no kadai nitibei kyouku kyouryoku kennkyuu houkokusho [Mutual educational tasks in Japan and the United States: 
Research paper on educational cooperation between Japan and the United States].Tokyo:Daiichi Houki, 1986. (in Japanese)

16. Industry and labor synthetic research institute. '98 moderu chingin jittai [Actual conditions of model wages in 1998], Tokyo: Keiei shoin, 1997. (in Japanese)

17. U.S. Department of Commerce, Bureau of Census. Money income of household, families, and persons in the United States:191. Current population reports; Series P. 60, 1992; no. 180.

18. Tsuji I, Nishino Y, Ohkubo T, et al. A Prospective Cohort Study on National Health Insurance Beneficiaries in Ohsaki, Miyagi Prefecture, Japan: Study Design, Profiles of the Subjects and Medical Cost During the First Year. J Epidemiol 1998; 8: 258-63.

19. Tsuji I, Kuwahara A, Nishino Y, Ohkubo T, Sasaki A, Hisamichi S. Medical cost for disability: a prospective observation of National Health Insurance beneficiaries in Japan. J Am Geriatr Soc, 1999; 47: 470-476.

20. Belloc N, Breslow, Relationship of physical health status and health practices. Prev Med. 1972; 1: 409-21.

21. Japan Obesity Society. Himanshou shindan, chiryo, shi- dou no tebiki [Handbook of diagnosis, treatment, and education for obesity] Tokyo: Ishiyaku shuppan, 1997, pp.17-18. (in Japanese)

22. SAS Institute Inc. SAS/STAT User's Guide, Release 6.03 Editon Cary, NC: SAS Institute, 1988.

23. Ministry of Education, Waga kuni no bunkyou shisaku heisei 9 nendo [A educational policy in Japan, 1998]. Tokyo, 1998; 520. (in Japanese)

24. Aoki $\mathrm{K}$ ed, The reports on baseline analysis for the national collaborative cohort study of cancer. Nagoya, Aichi Cancer Center, 1994.(in Japanese)

25. Fukao A, Tsubono Y, Komatsu S, et al. A cohort Study on the Relation of Lifestyle, Personality and Biologic Markers to Cancer in Miyagi, Japan: Study Design, Response Rate and Profiles of the Cohort Subjects. $J$ Epidemiol 1995; 5: 153-7.

26. Patterson RE, Haines PS, Popkin BM. Health lifestyle patterns of US adults. Prev Med 1994; 23: 453-60.

27. Kaplan GC, Camacho TC, Kaplan GA, Cohen RD. Alcohol consumption and mortality in Alameda county. J Chronic Diseases 1987; 40: 229-36. 